\title{
ANALISIS RANTAI PASOK KOMODITI CABAI RAWITDI PASAR BERSEHATI KOTA MANADO DI MASA PANDEMI COVID-19
}

\section{ANALYSIS OF THE SUPPLY CHAIN OF CABAI RAWIT COMMODITY IN THE BERSEHATI MARKET OF MANADO CITY IN THE PANDEMIC COVID-19}

\author{
$\underline{\text { Riffani Kansil }}^{(1)}$, Oktavianus Porajouw ${ }^{(2)}$, Rine Kaunang ${ }^{(2)}$
}

1) Mahasiswa Program Studi Sosek/Agribisnis, Fakultas Pertanian, Universitas Sam Ratulangi, Manado

2) Dosen Program Studi Sosek/Agribisnis, Fakultas Pertanian, Universitas Sam Ratulangi, Manado

*Penulis untuk korespondensi: fannykansil18@gmail.com

\begin{tabular}{ll}
\hline Naskah diterima melalui Email Jurnal Ilmiah agrisosioekonomi@unsrat.ac.id & : Senin, 29 Maret 2021 \\
Disetujui diterbitkan & : Jumat, 28 Mei 2021 \\
\hline
\end{tabular}

\begin{abstract}
This study aims to analysis the supply chain mechanism for the cayenne pepper commodity in the Bersehati Market of Manado City during the Covid-19 pandemic. The data used in this study are primary data and secondary data. Primary data were obtained from observations, direct interviews, and interviews via WhatsApp with traders, consumers, and service providers in the Bersehati market. Secondary data were collected and obtained from employees in the Bersehati Market. The sampling method was carried out using the purposive sampling method (deliberately), namely selecting sources of information in the Bersehati Market. Number of sample used in this study was taken 10 respondents divided into 5 retailers, 3 consumers, 1 service provider, 1 market officer. This study uses descriptive analysis which is an analytical method used to determine the supply chain mechanism of cayenne pepper. The results showed that the supply chain mechanism for the cayenne pepper commodity in the Bersehati Market during the Covid-19 pandemic was related to product flows, financial flows and information flows that had differences in each flow. During the pandemic, there were 6 links that played an active role in the supply chain for the chili commodity at the Bersehati Market.
\end{abstract}

Keywords: supply chain; cayenne pepper; commodity; covid-19 pandemic

\section{ABSTRAK}

Penelitian ini bertujuan untuk menganalisis mekanisme rantai pasok komoditi cabai rawit di Pasar Bersehati Kota Manado di masa pandemi Covid-19. Penelitian ini dilaksanakan dari bulan Juni-Oktober 2020. Data yang digunakan dalam penelitian ini adalah data primer dan data sekunder. Data primer diperoleh dari pengamatan, wawancara langsung dan wawancara melalui whatsapp dengan pedagang, konsumen dan penyedia jasa yang berada di pasar Bersehati. Data sekunder dikumpulkan dan diperoleh dari pegawai yang berada di Kantor Pasar Bersehati. Metode pengambilan sampel dilaksanakan dengan menggunakan metode purposive sampling (secara sengaja) yaitu memilih sumber-sumber informasi yang ada di Pasar Bersehati. Jumlah sampel yang digunakan pada penelitian ini sebanyak 10 responden yang terdiri atas: 5 pedagang pengecer, 3 konsumen, 1 penyedia jasa, 1 petugas pasar. Data yang dikumpulkan dianalisis secara deskriptif untuk memberikan gambaran tentang mekanisme rantai pasok cabai rawit di pasar Bersehati. Hasil penelitian menunjukkan bahwa mekanisme rantai pasok komoditi cabai rawit di Pasar Bersehati pada masa pandemi Covid-19 terkait dengan aliran produk, aliran keuangan dan aliran informasi memiliki perbedaan di setiap alirannya. Pada masa pandemi terdapat 6 mata rantai yang berperan aktif dalam rantai pasok komoditi cabai rawit di pasar Bersehati, yaitu petani, pedagang besar, pedagang pengumpul, pedagang pengecer, jasa dan konsumen.

Kata kunci: rantai pasok; komoditi; cabai rawit; pandemi covid-19 


\section{PENDAHULUAN}

Indonesia memiliki kekayaan sumber daya alam dan keanekaragaman hayati yang sangat tinggi, sejarah menunjukan bahwa sektor pertanian memegang peranan penting dalam pembangunan ekonomi secara keseluruhan. Sehingga kekayaan yang dimiliki harus dimanfaatkan dan dilestarikan dengan baik oleh masyarakat, sektor pertanian menjadi salah satu yang sangat penting bagi Indonesia, karena selain sumber kehidupan tapi juga menajdi sumber pendapatan dalam peningkatkan perekonomian negara, serta sebagai sumber bahan baku industri lainnya, dan juga menjadi sumber pangan, sandang dan papan bagi masyarakat Indonesia yang bermutu dan berkulitas. Hortikultura adalah salah satu sektor dalam pertanian yang memiliki jenis komoditas beragam dan merupakan sektor yang dibutuhkan masyarakat secara langsung. Cabai adalah tanaman yang tumbuh banyak di Nusantara, tanaman cabai banyak dibudidayakan di Indonesia karena mempunyai iklim tropis. Cabai dapat ditanam di dataran tinggi maupun dataran rendah sehingga cabai di Indonesia sangat berlimpah. Cabai adalah rempah-rempah bernilai tinggi sejak masa silam hingga sekarang, cabai yang merupakan hasil pertanian menjadi salah kebutuhan masyarakat Indonesia, khususnya masyarakat Sulawesi Utara Kota Manado. Ketersediaan Komoditi Cabai tidak diragukan lagi bagi masyarakat karena produksi cabai di Sulawesi Utara selalu tersedia, namun seringkali terjadi fluktuasi harga. Dari sisi konsumsi masyarakat Sulawesi Utara, cabai mempunyai pangsa yang cukup signifikan. Di kota Manado sering di temui bahwa harga cabai rawit kadang tinggi dan kadang rendah bahkan cenderung tidak menentu. Pasar Bersehati di Kota Manado merupakan salah satu pasar yang menjual berbagai macam komoditi, salah satunya komditi cabai. Sebagian besar pedagang mengambil pasokan komoditi cabai dari daerah Gorontalo, ataupun daerah lain seperti Minut, Palu dan Kotamobagu yang melakukan pasokan komoditi cabai namun cabai Gorontalo yang banyak di minati oleh konsumen. Di pasar Bersehati pengunjung yang datang dari berbagai daerah yang ada di Kota Manado sehingga pasar ini selalu ramai dengan konsumen. Namun pada saat ini terjadi permasalahan yang menimpa dunia termasuk juga Indonesia yang berimbas di Sulawesi Utara, berbagai daerah sudah terdampak virus corona atau covid-19, termasuk Kota Manado yang terkena dampaknya. Covid-19 adalah sebuah penyakit yang masih sangat baru dan para peneliti masih mempelajari tentang penyakit ini. Pandemi covid-19 memiliki dampak bagi masyarakat, termasuk pada perekonomian dan pola hidup. Pemerintah dalam mengatasi penyebaran covid19 , telah mengeluarkan aturan agar masyarakat melakukan perkejaan, belajar, beribadah, atau melakukan aktivitas dari rumah. Pada saat masa pandemi maka penjualan distribusi semua komoditi terjadi penurunan. Penelitian ini dilakukan untuk mendapatkan gambaran kondisi pasar tradisional pada masa pandemi covid-19 ini. Pembatasan sosial dan fisik sebagai akibat pandemi covid-19, menyebabkan konsumen mengalami kesulitan untuk belanja langsung ke pasar tradisional. Omset penjualan pedagang pengecer di pasar juga mengalami penurunan yang cukup signifikan. Penggunaan jasa online merupakan salah satu cara yang digunakan masyarakat untuk melakukan pasokan komoditi/produk kepada konsumen. Penggunaan jasa online tersebut berdampak pada mekanisme rantai pasok komoditi. Komoditi cabai rawit adalah komoditi yang sangat dibutuhkan masyarakat di Kota Manado sebagai bumbu masak, dan pasar Bersehati adalah salah satu pasar tradisional yang terletak di pusat kota Manado, dan merupakan penyedia komoditi cabe rawit terbesar. Berdasarkan pemikiran tersebut, penelitian ini dilakukan untuk menganalisis rantai pasok komoditi cabai rawit di pasar Bersehati Kota Manado di masa pandemi covid-19.

\section{Rumusan Masalah}

Berdasarkan latar belakang yang telah diuraikan maka rumusan masalah dalam penelitian ini adalah bagaimana mekanisme rantai pasok komoditi cabai rawit di pasar Bersehati Kota Manado pada masa pandemi covid-19.

\section{Tujuan Penelitian}

Tujuan penelitian ini adalah untuk menganlisis mekanisme rantai pasok komoditi cabai rawit di pasar Bersehati Kota Manado pada masa pandemi covid-19.

\section{Manfaat Penelitian}

1. Sebagai bahan pembelajaran bagi peneliti dan semua pihak yang berminat dalam mempelajari rantai pasok dengan komoditi cabai rawit di pasar Bersehati pada masa 
pandemi covid-19.

2. Penelitian ini diharapakan sebagai bahan pembelajaran dalam memanfaatkan dan mengembangkan teknologi informasi sebagai manfaat dalam analisis rantai pasok.

3. Penelitian ini dapat dijadikan refrensi bagi pemerintah dan pihak terkait dalam analisis rantai pasok cabai rawit di pasar Bersehati pada masapandemi covid-19.

\section{METODELOGI PENELITIAN}

\section{Waktu dan Tempat Penelitian}

Penelitian ini dilaksanakan dari bulan Juni-Oktober 2020 mulai persiapan hingga penyusunan laporan penelitian. Tempat penelitian dilaksanakan di pasar Bersehati Kota Manado sebagai salah satu pasar tradisional terbesar dalam menyediakan komoditi cabai rawit di Kota Manado.

\section{Metode Pengumpulan Data}

Penelitian ini menggunakan data primer dan data sekunder. Data primer diperoleh dari pengamatan, wawancara langsung dan wawancara melalui whatsapp dengan pedagang, konsumen dan penyedia jasa yang berada dipasar Bersehati. Data sekunder dikumpulkan dan diperoleh dari pegawai yang berada di pasar Bersehati.

\section{Metode Pengambilan Sampel}

Metode pengambilan sampel dilaksanakan dengan menggunakan metode purposive sampling (secara sengaja) yaitu memilih sumber-sumber informasi ada di pasar Bersehati. Dan jumlah responden yang digunakan pada penelitian ini diambil 10 responden yang terbagi atas: 5 pedagang pengecer, 3 Konsumen, 1 penyedia jasa, 1 petugas pasar.

\section{Konsep Pengukruan Variabel}

Variabel-variabel yang dapat di definisikan pada penelitian ini, adalah :

1. Aliran produk komoditi cabai rawit pada masa pandemi covid-19, yaitu penyaluran produk berupa komoditi cabai rawit di pasar bersehati.

2. Aliran informasi komoditi cabai rawit pada masa pandemi covid-19, berkaitan dengan proses komunikasi antar mata rantai yang terlibat dalam rantai pasokan cabai rawit yang meliputi pedagang pengumpul, pedagang pengecer, dan konsumen.

3. Aliran keuangan komoditi cabai rawit pada masa pandemi covid-19, yaitu nilai dalam bentuk rupiah dimana aliran keuangan tersebut terdiri dari biaya yang dibayarkan dan keuntungan yang diterima oleh setiap mata rantai yang terlibat dalam rantai pasok cabai rawit di pasar Bersehati.

\section{Metode Analisis Data}

Analisis rantai pasok komoditi cabai rawit di Kota Manado dilakukan dengan pendekatan aliran produk, aliran uang, dan aliran informasi yang terjadi dalam rantai pasok komoditi cabai di pasar Bersehati pada masa pandemi covid-19. Data yang dikumpulkan melalui wawancara, dan selanjutnya dideskripsikan untuk menjawab tujuan penelitian. Penelitian ini menggunakan analisis deskriptif yang merupakan suatu metode analisis yang digunakan untuk mengetahui mekanisme rantai pasok cabai rawit.

\section{HASIL DAN PEMBAHASAN}

\section{Deskripsi Objek Penelitian}

Pasar Bersehati dibangun tahun 1973 merupakan pasar terbesar di Kota Manado dengan jumlah pedagang dan kios terbanyak, \pm 500 kios, \pm 300 pedagang pengecer dan \pm 100 pengecer cabai yang terdapat di pasar Bersehati Kota Manado, pasar ini memiliki posisi yang terletak sangat strategis. Terletak bersebelahan dengan pelabuhan Manado, yang bagian atasnya dilewati jembatan Soekarno. Adapun lokasi dari pasar Bersehati ini terletak di Kelurahan Calaca, Kecamatan Wenang, Kota Manado. Pasar Bersehati memiliki luas $\pm 5.00 \mathrm{Ha}$ (Andreano, dkk.2017). Lokasinya adalah eks kuala Jengki yang direklamasi/ ditimbun oleh pemerintah.Selain menjual beraneka ragam barang dan bahan makanan, pasar Bersehati juga menjual baju-baju, tas, sepatu, accesories dan peralatan lainnya yang dibutuhkan masyarakat golongan ekonomi menengah ke bawah. Pengunjung yang datang ke pasar bersehati terdiri dari berbagai daerah yang berada di Kota Manado. Pasar Bersehati memiliki berbagai macam komoditi yang dijual, termasuk komoditi cabai rawit yang merupakan salah satu komoditi khas dan dibutuhkan masyarakat Kota Manado. 


\section{Manajemen Rantai Pasok Masa Pandemi Covid-19}

Penerapan sistem rantai pasok bagi produk pertanian membutuhkan suatu manajemen yang bertujuan menciptakan sistem rantai pasokan yang efisien dalam pelaksanaannya. Manajemen yang dibentuk oleh para anggota dalam mata rantai akan menghasilkan sebuah mekanisme dan pola kelembagaan yang dipilih oleh para pelaku dalam sistem rantai pasokan cabai rawit pasar Bersehati pada masa pandemi covid-19. Berikut anggota mata rantai yang terlibat dalam rantai pasok cabai di pasar Bersehati:

\section{Petani}

Produsen yang bergerak di bidang pertanian/memproduksi komoditi cabai, yang bertujuan untuk memelihara tanaman dengan harapan untuk memperoleh hasil dari tanaman tersebut untuk menjualnya kepada pedagang yang berada di pasar Bersehati.

\section{Pedagang pengumpul}

Pedagang yang melakukan aktivitas membeli cabai dari petani untuk kemudian dijual kepada pedagang besar di pasar Bersehati. Pedagang pengumpul melakukan kesepakatan kepada pedagang besar seperti penetapan jumlah cabai rawit yang diminta, harga jual dan biaya pengantaran serta sistem pembayaran kepada para pedagang besar, pemesanan dilakukan melalui telepon selular. Pedagang pengumpul melakukan perjanjian timbal balik antara pengangkut dengan pengirim, dimana pengangkut mengikatkan diri untuk menyelenggarakan pengangkutan cabai dari daerah pasokan yang biasanya daerah tempat pengampilan komoditi untuk menuju tempat tujuan yaitu di Pasar Bersehati. Pedagang yang mengumpulkan/membeli dari petani, hasil pertanian cabai rawit untuk kemudian menjualnya kembali kepada pedagang besar yang sudah mempunyai hubungan kerja sama kepada pedagang yang berada di Pasar Bersehati.

\section{Pedagang Besar}

Pedagang besar merupakan salah satu pihak yang memiliki peran penting dalam rantai pasok yang terjadi di pasar Bersehati, mereka melakukan kegiatan pembelian komoditi cabai dengan jumlah yang besar kepada pedagang pengumpul ataupun langsung kepada petani, pedagang besar biasanya menjadi penyalur komoditi cabai sampai pada tangan konsumen melalui pedagang pengecer. Pedagang besar memiliki kegiatan untuk mengelolah cabai yang ada dalam persediaan, dengan maksud selalu dapat menjamin ketersediaannya, menyortir atau memilih yang diperlukan dan mengeluarkan yang tidak diperlukan atau dengan arti lain yaitu kegiatan yang dilakukan dalam memilihmilih/memilah cabai yang berkualitas baik. Pedagang pengecer memperoleh komoditi cabai dari pedagang besar. Pedagang besar biasanya langsung mendatangi pedagang pengecer sesuai kesepakatan sebelumnya. Pada masa sebelum pandemi, kegiatan penyaluran komoditi seperti biasa lancar karena pasar bisa disebut ramai namun pada masa pandemi terjadi kendala penyaluran komoditi cabai sedikit terhalang akibat pandemi yang terjadi. Pasokan cabai pedagang besar kepada pedagang pengumpul mencapai $100 \mathrm{~kg}$ sesuai dengan kesepakatan antara pedagang besar dan pedagang pengumpul atau pun secara langsung kepada petani bisa per hari sesuai dengan kesepakatan yang dilakukan.

\section{Pedagang Pengecer}

Pedagang pengecer merupakan pelaku rantai pasok yang melakukan kegiatan pembelian komoditi cabai dari pedagang besar. \pm 100 pedagang pengecer cabai yang berada di pasar Bersehati melakukan kerja sama dengan Pedagang besar dalam penyaluran komoditi. Kegiatan dari pedagang pengecer yaitu memilih atau dengan arti lain mereka memilih cabai-cabai yang berkualitas baik untuk dijual ke konsumen, dan biasanya cabai yang berasal dari Gorontalo memiliki kualitas yang baik sehingga diminati oleh masyarakat Kota Manado. Pedagang pengecer yang biasanya memilki kerja sama dengan beberapa industri rumah makan namun pada masa pandemi tidak terjalin karena sebagian industri rumah makan tutup akibat pandemicovid-19.

\section{Jasa}

Penyedia jasa online merupakan pelaku rantai pasok yang bermafaat pada masa pandemi covid-19. Anjuran pemerintah untuk tetap berada dirumah pada masa pandemi membuat sebagian masyarakat memanfaatkan jasa online untuk melakukan pembelian barang, termasuk cabai rawit. Pelaku jasa online biasanya melakukan pembelian langsung ke pedagang pengecer sesuai 
dengan permintaan konsumen. Pada masa pandemi jasa online yang berada di pasar Bersehati salah satunya adalah pihak Bank Indonesia bekerja sama dengan pedagang pengecer yang berada dipasar bersehati, dan kemudian mereka membagikan kontak-kontak pedagang lewat poster yang diposting di sosial media untuk dihubungi lewat whatssup, kemudian dari konsumen bisa menghubungi langsung ke pedagang dalam proses pembelian, dan pedagang menganjurkan konsumen untuk melakukan pembelian jasa online seperti aplikasi grab/gojek. Harga jual yang ditawarkan ke konsumen sama dengan pedagang pengecer, namun konsumen harus membayar kepada pelaku jasa online ongkos kirim dari pasar bersehati ke alamat rumah konsumen sesuai dengan jarakyang diberikan.

\section{Konsumen}

Konsumen merupakan rantai pasok yang terakhir selaian masyarakat Kota Manado, ada berbagai macam konsumen yang berkunjung di pasar Bersehati dan juga beberapa industri rumah makan yang menjadi konsumen komoditi cabai di pasar Bersehati.

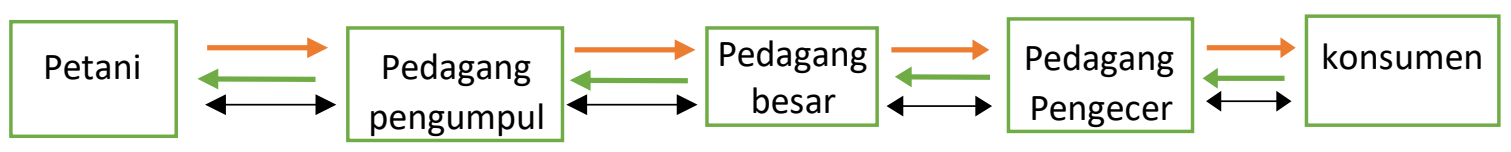

Gambar 2. Saluran I distribusi cabai rawit pada masa pandemi

\section{Keterangan : $\quad \longrightarrow=$ Aliran Produk \\ $\underset{\longleftarrow}{\longleftarrow}=$ Aliran Keuangan}

\section{Aliran Produk}

Aliran produk yang terjadi dalam saluran I pada masa pandemi covid-19 yaitu dari petani komoditi cabai yang biasanya dari luar daerah yaitu dari Gorontalo, Palu, Kotamobagu dan Minut yang melakukan kegiatan produksi komoditi cabai di Pasar Bersehati. Cabai yang paling diminati konsumen adalah cabai dari Gorontalo, namun pemasok yang berkaitan dengan aliran produk atau layanan penyedia komoditi mengalami dampak dan gangguan akibat pandemi yang terjadi sehingga keterlambatan pengiriman komoditi cabai atau logistik karena provinsi Gorontalo melakukan PSBB sehingga sulit untuk melakukan pasokan komoditi cabai, namun aliran produk komoditi cabai tetap terjadi pasokan yaitu dari Kabupaten Minahasa Utara yang sebagai pengganti pasokan komoditi cabai. Pedagang pengumpul memperoleh cabai rawit dari petani dan melakukan transaksi dengan pedagang besar, kesepakatan biaya pengangkutan dan pengantaran komoditi cabai dari pedagang besar dan pengecer sudah disepakati antar kedua pihak dalam menyaluran produk ke pasar Bersehati. Aliran produk antar pedagang besar dan pedagang pengecer seperti pada umumnya, namun pada masa pandemi covid-19 pengambilan komiditi cabai hanya berkisar $20 \mathrm{~kg}-40 \mathrm{~kg}$ yang pada sebelumnya mencapai $100 \mathrm{~kg}-300 \mathrm{~kg}$ cabai yang diambil oleh setiap pengecer, ini mengalami penurunan pengambilan stok pada pedagang pengecer karena kurangnya pengunjung di masa pandemi. Pesediaan komoditi pada setiap tahap terkait dengan uang, maka sangatlah penting jika operasi dari setiap tahap disinkronisasikan untuk dapat diupayakan agar persediaan penyangga dapat diminimalkan pada masa pandemi covid-19.

\section{Aliran Keuangan}

Aliran keuangan yang terjadi dalam saluran I komoditi cabai yaitu dari pedagang besar kepada pedagang pengumpul di pasar Bersehati, pedagang pengecer kepada pedagang besar dan konsumen kepada pedagang pengecer. Kesepakatan antara pedagang besar dan pedagang pengumpul sudah dihitung dengan biaya dan harga pasaran komoditi cabai yang sudah disepakati antar kedua pihak. Mekanisme aliran keuangan ditekankan pada sistem transaksi pembayaran dan pada saluran I ini sistem transaksi pembayaran dilakukan secara tunai. Sistem transaksi pembayaran antar pedagang besar dengan pedagang pengumpul terjadi saat komoditi cabai siap diangkut oleh pedagang besar, selanjutnya antar pedagang pengecer dengan pedagang besar dan konsumen dengan pedagang pengecer. 


\section{Aliran Informasi}

Aliran informasi yang terjadi dalam saluran I komoditi cabai meliputi informasi kuantitas/jumlah permintaan-persediaan dan informasi harga serta informasi waktu. Pedagang pengecer akan mengecek ketersediaan stok komoditi, informasi harga disepakati dengan melihat harga pasaran dan jumlah permintaan kesepakatan melalui Via Telepon antar pedagang pengecer pengecer dan pedagang penampung.Kemudian pedagang penampung akan menghubungi langsung pedagang besar yang biasanya melalui telpon untuk ketersediaan stok komoditi cabai. Pada saat pandemi covid-19 ketersediaan cabai ada namun permintaan menurun karena pandemi. Penentuan harga untuk cabai tergantung pada kualitas dan permintaan yang diminta. Informasi waktu melakukan pembelian komoditi cabai ditentukan dan disampaikan pedagang besar kepada pedagang pengecer, hal ini dilakukan supaya saat kegiatan pembelian komoditi cabai didapatkan dengan keadaan dan kualitas baik.

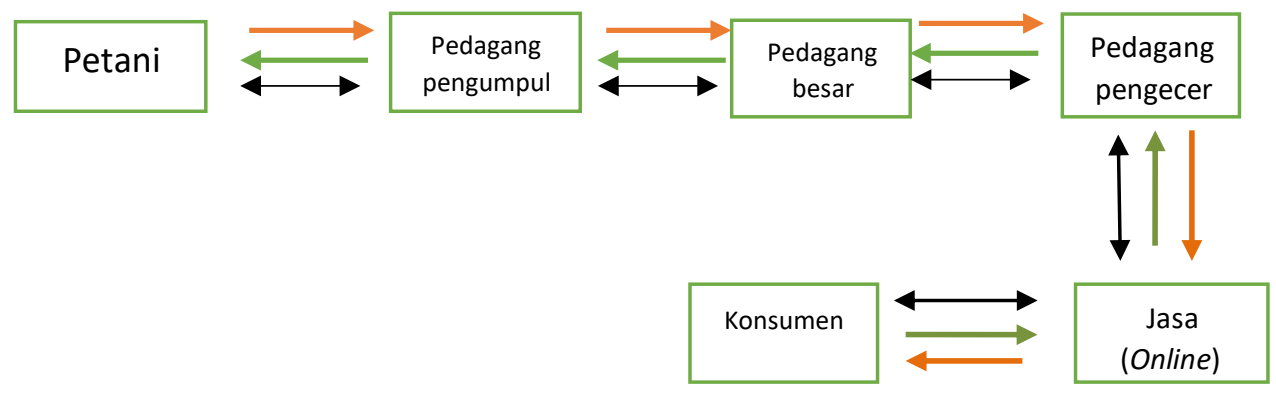

Gambar. 3. Saluran II distribusi cabai rawit pada masa pandemi

Keterangan : $\longrightarrow=$ Aliran Produk

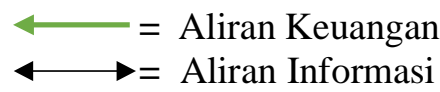

Saluran rantai pasok yang kedua pada komoditi cabai di pasar Bersehati pada masa pandemi covid-19 ini sedikit mengalami perubahan saluran dari saluran I dan saluran II, pedagang besar melakukan transaksi kepada pedagang pengcer di pasar Bersehati, selanjutnya pedagang pengecer melakukan transaksi tidak langsung dengan konsumen namun melalui jasa online atas permintaan konsumen yang memanfaatkan jasa online dalam melakukan pembelian di pasar Bersehati akibat pandemi yang terjadi.

\section{Aliran Produk}

Aliran produk yang terjadi dalam saluran II dari petani komoditi cabai yang biasanya beasal dari Gorontalo, Minut, Palu dan Kotamobagu melakukan kegiatan produksi komoditi cabai di pasar Bersehati, yang kemudian komoditi cabai dijual kepada pedagang besar melalui pedagang pengumpul. Selanjutnya disalurkan kepada pedagang-pedagang pengecer yang berada di pasar Bersehati, namun pada saluran ini komoditi cabai tidak langsung sampai ke tangan konsumen namun melalui penyedia jasa online yang digunakan oleh konsumen. Aliran produk komoditi cabai dari setiap pasokan tetap terjadi pada masa pandemi, namun aliran produk mengalami perubahan pada saluran II yang dimana peran jasa online sangat dibutuhkan untuk terjadinya rantai pemasaran pada komoditi cabai dipasar bersehati. Peran setiap pelaku rantai pasok sangatlah penting dalam terjadinya aliran produk komoditi cabai di pasar Bersehati.

\section{Aliran Keuangan}

Aliran keuangan pada saluran II komoditi cabai di pasar Bersehati yaitu dari pedagang besar pada pedagang pengumpul yang melakukan kegiatan produksi komoditi cabai, pedagang pengecer kepada pedagang besar dan penyedia jasa kepada pedagang pengecer dan selanjutnya dari konsumen kepada penyedia jasa yang digunakannya. Mekanisme yang terjadi dalam aliran keuangan pada saluran II sistem transaksi secara tunai. Pada masa pandemi pendapatan setiap pelakunya berubah karena mengalami 
penurunan pendapatan bagi para pedagang namun menguntungan bagi penyedia jasa online karena digunakan oleh konsumen dalam melakukan belanja online.

\section{Aliran Informasi}

Aliran informasi yang terjadi pada saluran II komoditi cabai di pasar Bersehati meliputi kuantitas/jumlah permintaan dan informasi harga pada komoditi. Mekanisme yang terjadi dimana konsumen menginformasikan jumlah permintaan kepada penyedia jasa yang digunakannya bisa melalui aplikasi online gojek/grab atau program dari Bank Indonesia yang membagikan kontakkontak para pedagang pengecer yang berada di Pasar Bersehati. Setelah terjadi kesepakatan antara keduanya, kemudian jasa online yang digunakan melakukan transaski secara langsung dengan pedagang pengecer yang ada di pasar Bersehati sesuai dengan permintaan kesepakatan yang dilakukan oleh konsumen dan penyedia jasa.

Sistem distribusi dari produsen ke konsumen dapat terdiri dari berbagai rantai pemasaran dimana masing-masing pelaku pasar memberikan jasa yang berbeda. Ada masanya situasi dan lingkungan yang melingkupi sebuah rantai pasok pangan mengalami perubahan yang cepat sesuai dengan keadaan yang terjadi, seperti pada saat ini terjadi pandemi covid-19. Prioritas utama dalam mengatasinya adalah menyelesaikan tantangan kesehatan dan dampak kemanusiaan adanya pandemi ini. Pembatasan fisik dan sosial yang diberlakukan di masa pandemi covid-19 menyebabkan penurunan pengunjung atau konsumen yang datang di pasar Bersehati. Perubahan atau tindakan yang diambil oleh anggota rantai pasok akan berdampak pada anggota rantai pasok yang lain, ini terlihat seperti yang terjadi di pasar Bersehati dimana pedagang pengcer mengalami penurunan pendapatan akibat kurangnya konsumen, pada situasi seperti ini, kolaborasi dan kerja sama semua pihak yang terkait baik pelaku utama ataupun pelaku pendukung, dalam rantai pasok komoditi cabai diperlukan. Pemberlakuan WFH dalam pencegahan penyebaran virus corona di Indonesia, setiap instansi pemerintahan, lembaga, ataupun perusahaan tentu memikirkan strategi agar setiap pegawai yang menjalankan kebijakan tersebut dapat tetap bekerja secara optimal. Hal ini juga berdampak terhadap operasional kegiatan dan layanan bisnis di pasar Bersehati. Badan Siber dan Sandi Negara (2020), tahapan strategi yang paling penting dan berkaitan dengan proses operasional perusahaan dan manajemen risiko keamanan rantai pasok untuk meminimalisasi dampak virus corona terhadap proses kelangsungan bisnis adalah tahapan persiapan dan perencanaan. Secara umum, semua pelaku dan pendukung telah merasakan adanya perubahan situasi karena pandemi. Dampak bagi setiap pelaku rantai pasok komoditi cabai di pasar Bersehati yaitu mengalami penurunan permintaan secara signifikan yang dialami setiap pelaku rantai terlebih khusus bagi para pedagang pengecer, namun mengalami keuntungan bagi para penyedia jasa online karena digunakan oleh konsumen.

\section{KESIMPULAN DAN SARAN}

\section{Kesimpulan}

Berdasarkan hasil penelitian ini menyimpulkan bahwa mekanisme rantai pasok komoditi cabai rawit di pasar Bersehati Kota Manado pada masa pandemi covid-19 terkait dengan aliran produk, aliran keuangan, dan aliran informasi memiliki perbedaan pada setiap alirannya. Terdapat enam mata rantai yang berperan aktif dalam rantai pasok komoditi cabai di pasar Bersehati pada masa pandemi, yaitu; petani, pedagang besar, pedagang pengumpul, pedagang pengecer, jasa dan konsumen.

\section{Saran}

Berdasarkan hasil penelitian yang dilakukan maka dapat disarankan bahwa perlu diperhatikan saluran distribusi komoditi cabai rawit di pasar Bersehati Kota Manado pada masa covid-19 agar aliran produk tetap tersalur ke konsumen. Dan bagi para konsumen dapat meningkatkan dalam memanfaatkan media sosial dalam memenuhi kebutuhan pada masa pandemi covid-19.

\section{DAFTAR PUSTAKA}

Agus Nurafiyanto. 2012. Pemasaran. http://agusnurafianto.blogspot.in/2012/0

6Diakses 19 November 2014.

Asmarantaka, dkk. 2017. Konsep Pemasaran Agribisnis : Pendekatan Ekonomi dan 
Manajemen Agrbisnis. Jurnal Agribisnis Indonesia Vol 5 No 2. Institut Pertanian Bogor

Assauri, Sofjan. 2014. Operational Strategic : Lean Operation Process. Jakarta : Rajawali Pers.

Andreano, T, dkk. 2017. Redesain Kompleks Pasar Bersehati Manado. Agriculture Waterfront. Arsitektur Universitas Sam Ratulangi

Badan Siber dan Sandi Negara. 2020. Panduan Keamanan Siber Manajemen Risiko Keamanan di Tengah Pandemi Covid-19.

Budiman, E. V. 2013. Evaluasi Kinerja Supply Chain Pada UD. Maju Jaya di Desa Tiwoho Kabupaten Minahasa Utara. Jurna IEMBA, Vol. 1, No. 4.

Christien, et al .2006. Quantifying the Agri Food Supply Chain. Netherlands : Spinger International Publisher Science

Chopra, S.dan Meindl, P. (2004). "Supply Chain Management". New Jersey: Pearson Education

Chopra, Sunil. 2013. Supply Chain Management Fifth Edition

England : Pearson

Haryanto S., dkk. 2018. Saluran Distribusi Komoditi Cabai Rawit di Pasar Bersehati Kota Manado. Agri-SosioEkonomi Unsrat, ISSN 1907-4298,Volume 14 Nomor.2

Indrajit, R.E., Djokopranoto, R. 2002. Konsep Manajemen Supply Chain: Cara Baru Memandang Mata Rantai Penyediaan Barang. Grasind

Laksana, F. 2008. Manajemen Pemasaran. Graha Ilmu. Yogyakarta.

Levi, David, and S. Levi. 2003. Desinging and Managing The Supply Chain: Concept, Strategies and Case Studies. Irwin McGraw-Hill, Singapore.
Marimin, Nurul M. 2010. Aplikasi Teknik Pengambilan Keputusan dalam Manajemen Rantai Pasok. Bogor: Unit Penerbit dan Percetakan IPB Press

Marimin, Maghfiroh N. 2013. Teknik dan analisis pengambilan keputusan fuzzy

dalam manajemen rantai pasok. Bogor (ID): IPB Press.

Pujawan, I. N. 2005. Supply Chain Management. Guna Jaya. Surabaya.

Qhoirunisa, A. 2014. Rantai Pasok Padi di Kabupaten Bogor Jawa Barat. (Thesis).

Bogor : IPB

Saptana, dkk, 2018. Manajemen Rantai Pasok Komoditas Cabai Pada Agroekosistem Lahan Kering di,Analisis Kebijakan Pertanian, Vol. 16 No.1

Saptana, Zakaria AK, dkk. 2017. Analisis manajemen rantai pasok komoditas cabai di lahan kering. Bogor (ID): Pusat Sosial dan Ekonomi dan Kebijakan Pertanian.

Setiawan,M. H., Perdana T., Handayanti , Y. 2020. Rantai Pasok Pangan Di Masa Masa Corona. Policy Brief. Bandung.

Simchi-Levi D, Kaminsky P. 2003. Designing, and managing the supply chain: concepts, strategies and case studies. New York (US): Mcgraw-Hill.

Tjiptono, F. 2007. Strategi Pemasaran. Edisi kedua.penerbit Andi, Yogyakarta. Wibowo, A. 2014. Analisis Kinerja Manajemen Rantai Pasokan Pada KUD Susu

Sumber Makmur Ngantang. Skripsi Universitas Muhammadiyah Malang.

Zaroni. 2017. Logistic \& Supply Chain : Konsep Dasar - Logistik Kontemporer Praktik Terbaik. Jakarta : Prasetya Mulya Publishing. 